\title{
ERYTHROPITTA CELEBENSIS.
}

\author{
Celebean Pitta.
}

\begin{abstract}
Pitta celebensis, Müller \& Schlegel, Verh, nat. Geschied., fol., Zool. Pitta, fol,, p. 18, no. 16 (1839-44, ex Forster MS.).-Gray, Genera of Birds, i. p. 213 (1846).-Westerman, Bijdr. tot de Dierkunde, folio, i. p. 46, pl. iii. (1848-54).-Wallace, Ibis, 1860, p. 142,-Schlegel, Mus. Pays-Bas, Pitta, p. 6 (1863).-Id. Vog. van Nederl. Indië, Pitta, pp. 17, 34, pl. iv. figs. 4, 5 (1863).—Wallace, Ibis, 1864, p. 105.-Gray, Hand-list of Birds, i. p. 296, no. 4377 (1869).-Schlegel, Mus. Pays-Bas, Revue Pitta, p. 10 (1874).Salvad. Ann. Mus. Civic. Genov. vii. p. 663 (1875).-Meyer in Rowley's Ornith. Misc. part viii. (1877).-Gould, Birds of Asia, part vii. (1878).

Brachyurus celebensis, Bonap. Consp. Gen. Av. i. p. 253 (1850).-Elliot, Monogr. Pittidæ, pl. xvii. (1863).-Id. Ibis, 1870 , p. 418.

Erythropitta celebensis, Bonap. Consp. Volucr. Anisod. p. 7 (1854).-Walden, Trans. Zool. Soc. viii. p. 62 (1872). -Meyer, Ibis, 1879, p. 126.-Wardlaw-Ramsay, Orn. Works of Marquis of Tweeddale, p. 164 (1881).
\end{abstract}

I HAVE already, in one of myother articles, spoken of the distribution of the red-breasted Pittas in the Malay archipelago; and below I quote the remarks of Dr. Meyer on this subject; I therefore need only say that the present species is the representative of that section of the genus on the island of Celebes, to which it appears entirely restricted. It is true that, in his Review of the Pittas contained in the Leiden Museum, Professor Schlegel enumerates several examples from the island of Siao in the Sanghir archipelago; but these no donbt belong to the species since named Pitta palliceps by the late Dr. Brüggemann. Certain differences, indeed, seem to have struck Professor Schlegel at the time; for he says that in the birds from Siao the rufous colour of the head is paler than in examples from Celebes, and often replaces the black bordering the blue stripe on the head.

Mr. Wallace found the species scarce in Northern Celebes, which appears to be the only part of the island where it has yet been found. I may be mistaken in this, as the localities Modélido, Négri-lama, and Boné, mentioned in the list of specimens at Leiden, do not occur in any of the maps I have examined. The other places, however, Menado, Gorontalo, and Tondano are situated in the northern part of Celebes ; and Dr. Beccari, although he collected at Buton, in the south-west corner of the island, only met with this Pitta at Kema, in the north. The presumption, at least, is, that, even if it is found all over the island, it is more abundant in the northern portion.

Count Salvadori mentions that the specimen shot by Dr. Beccari at Kema had the outermost of the smaller wing-coverts close to the bend of the wing marked with white-a feature not previously noted or figured in the plates of the species which have at present appeared.

Dr. Meyer has published the following note :-

"Although the red-breasted Pitta of Celebes is not so difficult to procure as the black-headed, it is nevertheless a bird which it is not easy to get a shot at, being very quiet in the daytime, and seldom calling except in the morning and evening its tumü tchui. In the evening the cry oppo (origin of the native name) is heard, with which male and female call one another, the note sounding melancholy and protracted. 'Oppo' means, in the language of the country, 'grandfather'; and the natives tell a tale, that once a child had gone with its grandfather into the forest, got astray, and was transformed into a bird, which now always calls for its grandfather. Pitta celebensis only runs on the ground, and is very shy and watchful; it glides noiselessly through the leaves; and, as its back is green, it can only with difficulty be detected. To approach it one must creep through the densest bushes; and without imitating the call of the bird its pursuit would be in vain; but if the hunter imitates the cry, he can draw the bird almost to the muzzle of bis gun. During the daytime they go singly, in the evening in pairs together. The nest is to be found in brushes, near small pools. The bird digs a hole in the slope of the river-bank, and builds its nest therein, of wood and leaves, lined with cotton or hairy-plant materials (for instance, from Arrenga saccharifera, Lab.). It lays two eggs. If the female sits on the eggs, the male watches in the neighbourhood, and he takes the place of the female when she goes for food. This Pitta feeds on beetles, small caterpillars, \&ic."

The soft parts are noted by Mr. Wallace to be as follows in freshly killed specimens :- " Bill blackishhorny ; feet dusky lead-colour; iris pale olive."

The figures in the Plate are of the size of life, and are drawn from examples in my own collection. 


\section{$2 \mathrm{BHL}$ Biodiversity Heritage Library}

Gould, John. 1881. "Celebean Pitta, Erythropitta celebensis." Monograph of the Pittidae 2, -. https://doi.org/10.5962/p.323520.

View This Item Online: https://www.biodiversitylibrary.org/item/226386

DOI: https://doi.org/10.5962/p.323520

Permalink: https://www.biodiversitylibrary.org/partpdf/323520

\section{Holding Institution}

Smithsonian Libraries

\section{Sponsored by}

Biodiversity Heritage Library

\section{Copyright \& Reuse}

Copyright Status: Public domain. The BHL considers that this work is no longer under copyright protection.

This document was created from content at the Biodiversity Heritage Library, the world's largest open access digital library for biodiversity literature and archives. Visit BHL at https://www.biodiversitylibrary.org. 